\title{
ARTYKULY \\ GÓRY HEMOS JAKO MIEJSCE SCHRONIENIA, BAZA WYPADOWA I PUNKT OBSERWACYJNY W ŚWIETLE BUŁGARSKO-BIZANTYŃSKICH ZMAGAŃ ZBROJNYCH OKRESU WCZESNEGO ŚREDNIOWIECZA
}

\author{
KIRIŁ MARINOW
}

\begin{abstract}
Kirił Marinow, Góry Hemos jako miejsce schronienia, baza wypadowa i punkt obserwacyjny $w$ świetle bułgarsko-bizantyńskich zmagań zbrojnych okresu wczesnego średniowiecza (The Haemus Mountains as a shelter, an attack outpost and an observation post in the light of the Bulgarian-Byzantine military relations in the early Middle Ages).

Balcanica Posnaniensia. Acta et studia, XX, Poznań 2013, Wydawnictwo Instytutu Historii UAM, pp. 5-17, ISBN 978-83-63047-36-1, ISSN 0239-4278. Polish text with a summary in English.

Kirił Marinow, Uniwersytet Łódzki, Wydział Filozoficzno-Historyczny, Instytut Historii, Katedra Historii Bizancjum, ul. Aleksandra Kamińskiego 27a, 90-210 Łódź, Polska-Poland.
\end{abstract}

W średniowieczu mieszkańcy Wschodniego Rzymu nazwą Hemos (tur. Balkan) określali przede wszystkim dwa pasma górskie, które przedzielają na pół, biegnąc równoleżnikowo, obszary północno-wschodnich Bałkanów, konkretnie zaś terytorium obecnej Bułgarii. Chodzi mianowicie o masywy współczesnej Starej Płaniny i przylegającej do niej od południa Srednej Gory, które łukiem znad dolnego Dunaju, na zachodzie, ciagną się aż do wybrzeży Morza Czarnego, na wschodzie. W ten sposób tworzą wyraźną barierę geograficzną, oddzielając znajdujące się na północy od nich obszary Niziny Naddunajskiej, na której w okresie wczesnośredniowiecznym lokowało się centrum państwa bułgarskiego, od Tracji, stanowiącej w tym czasie bądź to teren buforowy i graniczny pomiędzy Bizancjum a Bułgarią, bądź to strefę stałego konfliktu zbrojnego między tymi państwami. Hemos odgrywał przeto istotną rolę geopolityczną w tej części Półwyspu Bałkańskiego, wpływając na losy otaczających go krain ${ }^{1}$. Fakt ten został rozpoznany przez Bułgarów już w początkowej fazie budowania przez nich „nowej ojczyzny” nad dolnym Dunajem.

\footnotetext{
${ }^{1} \mathrm{Na}$ temat tego masywu cf. m.in. Л. Динев, Л. Мелнишки, Стара планина, София 1962; Г.Д. Данов, Средна Гора. Пътеводител, София 1971; P. Soustal, Thrakien (Thrakē, Rodopē und Haimimontos), Tabula Imperii Byzantini, Bd. VI, Wien 1991, s. 279-280; К. Гагова, Тракия през българското Средновековие. Историческа география, София 2002, s. 319-322; В. Николов, М. Йорданова, Планините в България, София 2002, s. 9-57.
} 
Dziejopisarze bizantyńscy wyraźnie dali do zrozumienia, że Bułgarzy już w momencie opanowania obszarów dawnych rzymskich prowincji Scytii Mniejszej i Mezji Dolnej realizowali strategię obronną, polegającą na zasiedlaniu terytoriów wyodrębnionych i zewsząd zamkniętych naturalnymi granicami. Teofanes Wyznawca podał, że zajęli oni tereny w pobliżu Odessos i tzw. Warny

widząc, że miejsce jest w pełni zabezpieczone, z tyłu przez rzekę Dunaj, z przodu zaś i z boku przez klisury [tzn. wąskie przejścia górskie - K.M.] i morze Pontyjskie...

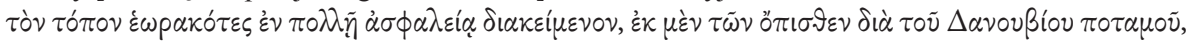

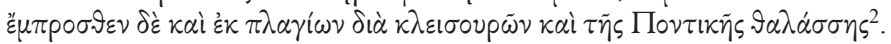

Identyczny w swej wymowie jest tekst patriarchy Nikefora:

gdy spostrzegli miejsce warowne i bezpieczne ze wszystkich stron, dzięki rzece i trudnemu terenowi, osiedlili się tam

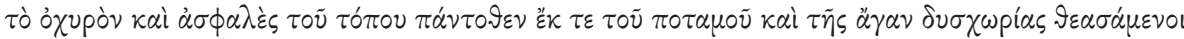
$\dot{\varepsilon} \nu \tau \alpha \tilde{\nu} \vartheta \alpha \sigma \kappa \eta \nu \circ \tilde{v} \sigma \iota^{3}$.

Wymienione w tekstach klisury i trudny teren należy identyfikować z pasmem Starej Płaniny. Świadczy to o doskonałym zmyśle strategicznym Bułgarów i umiejętności trafnego oceniania walorów obronnych terenów górskich. Bułgarzy nie ograniczyli się jednak wyłącznie do położenia swej ufności w walorach strategicznych wymienionych przez źródła naturalnych granic zdobytego obszaru.

W świetle przekazu tych samych historyków, po narzuceniu swej zwierzchności miejscowym plemionom słowiańskim, Bułgarzy

przesiedlili Sewerów [Siewierzan - K.M.] mieszkających przed przełęczą Weregawa w okolice wschodnie, a pozostałych Siedem Plemion im podległych na południe i zachód aż do granic Awarii,

2 Theophanis chronographia, AM 6171, ed. C. de Boor, vol. I, Lipsiae 1883 (dalej: Teofanes), s. 359, 5-12 (jeżeli nie zaznaczono inaczej tłumaczenia w tekście są mojego autorstwa - K.M.). Ostatnie podsumowanie wyników badań archeologicznych nad Dolnym Dunajem zdaje się potwierdzać, że Asparuch rzeczywiście uczynił z Dunaju północną granicę swego chanatu - U. Fiedler, Bulgars in the Lower Danube region. A survey of the archaeological evidence and of the state of current research, w: The Other Europe in the Middle Ages. Avars, Bulgars, Khazars, and Cumans, ed. F. Curta with the assistance of R. Kovalev, Leiden-Boston 2008, s. 152, 159-162. Cf. В. Тьпкова-Заимова, Долни Дунав-гранична зона на византийския запад. Към историята на северните и североизточните български земи, края на X-XII в., София 1976, s. 21; J.V.A. Fine jun., The Early Medieval Balkans. A Critical Survey from the Sixth Century to the Late Twelfth Century, Ann Arbor 1983, s. 67.

${ }^{3}$ Nicephori Patriarchae Constantinopolitani breviarium historicum, 36, ed. C. Mango, Washingtoniae D.C. 1990 (dalej: Nikefor, Zarys historii), s. 90, 21-23; thum. - Testimonia najdawniejszych dziejów Stowian. Seria grecka, z. III, Pisarze z VII-X wieku, wydali A. Brzóstkowska i W. Swoboda, Warszawa 1995 (dalej: Testimonia), s. 124. O ograniczeniu tego obszaru naturalnymi przeszkodami geograficznymi wzmiankował także Manuel Straboroman - P. Gautier, Manuel Straboromanos, „Revue des études byzantines", t. 23, 1965, s. 190, $23-191,1$. 


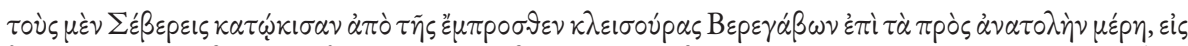

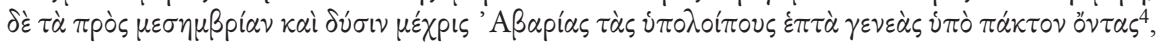

innymi słowy,

pokonali także mieszkających w pobliżu Sklawenów i jednym kazali strzec terenów leżących blisko Awarów, innym zaś pilnować tych, które sąsiadowały z Romejami

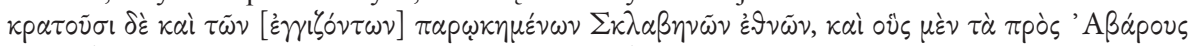

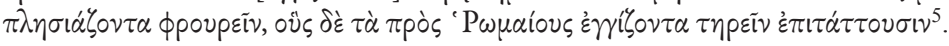

Z tekstów tych wyraźnie wynika, że Asparuch, ówczesny bułgarski władca, dodatkowo wzmocnił i tak naturalnie obronne obszary graniczne. Siewierzanie zostali przesiedleni ku wschodowi, prawdopodobnie po to, aby strzegli skrajnych przełęczy Hemosu i brzegów Morza Czarnego. Z kolei pozostałym Siedmiu Plemionom powierzono zadanie obrony reszty klisur bałkańskich, jak również granicy z Awaramí . Wedle przekazu Teofanesa dopiero, gdy zajęli wymienione terytorium i umocnili jego granice, Bułgarzy

poczuli się... pewni siebie, zaczęli więc napadać i grabić terytoria należące do państwa romejskiego,

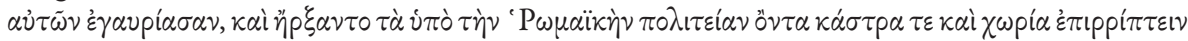

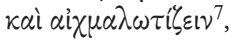

co uściśla patriarcha Nikefor, wedle którego

zaczęli pustoszyć osady i miasta trackie

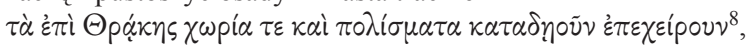

\footnotetext{
${ }^{4}$ Teofanes, AM 6171, s. 359, 5-6, 12-17; thum. - Testimonia, s. 56 (z moimi drobnymi zmianami K.M.).

${ }^{5}$ Nikefor, Zarys historii, 36, s. 90, 23-26; thum. - Testimonia, s. 124. Cf. Georgii Cedreni, Ioannis Skylitzae opera, ed. I. Bekker, vol. I, Bonnae 1838, s. 770, 3-5, wedle którego Bułgarzy rozłożyli się w jakichś gęstwinach i górach.

${ }^{6}$ Cf. Г. Баласчев, Укрепителните работи на старобългарската войска, „Минало”, t. 3, 1918, 10/1, s. 9. Na to, iż Siewierzanie bronić mieli wybrzeży czarnomorskich, zwracał uwagę Iwan Dujczew И. Дуйчев, Извори за историята на Черноморието, w: Средновековна България и Черноморието (Сборник доклади от научната конференция Варна - 1980), със. А. Кузев, ред. Т. Йорданов, Варна 1982, s. 8-9; idem, Обединението на славянските племена в Мизия през VII в. Към въпроса за възникването на българската държава, w: idem, Българско средновековие. Проучвания върху политическата и културната история на средновековна България, София 1972, s. 72-73. Pogląd jego przyjęli X. Димитров, Славяни и прабългари по Западното Черноморско крайбрежие до края на $I X$ век, „Годишник на Софийския Университет. Научен Център за Славяно-византийски проучвания “Иван Дуйчев’”, t. 84/85, 1990/1991, 4, s. 85; И. Божилов, Х. Димитров, Protobulgarica (заметки по истории протоболгар до середины IX в.), „Вуzantinobulgarica”, t. 9, 1995, s. 44. Г. Атанасов, Нов поглед към демографските и етнокултурните промени в Добруджа през Средновековието, „Studia Balcanica”, t. 23, 2001, s. 187-188, dopuszcza, że akcja wysiedlania Słowian objęła jedynie obszar pomiędzy Pliską, Presławiem a Warną. U. Fiedler, op. cit., s. 154, 158, wskazuje natomiast, że Bułgarzy zajęli obszar na północ od linii Warna - Szumen, a Siewierzanie na południe od niej.

7 Teofanes, AM 6171, s. 359, 17-19; thum. - Testimonia, s. 56.

${ }^{8}$ Nikefor, Zarys historii, s. 90, 26-27. Cf. Sigeberti Gemblacensis chronographia, AD 680, ed. D.L.C. Bethmann, [in:] MGH.SS, vol. VI, s. 326, 60-63.
} 
a więc leżące na południe od masywu Starej Płaniny. Bułgarzy nie podjęli zatem najazdów na Trację ${ }^{9}$, dopóki nie mieli pewności, że przynajmniej w danym momencie nie zapewnili sobie minimum bezpieczeństwa. Po rozlokowaniu straży w przełęczach bałkańskich mogli liczyć, że w razie zagrożenia góry będą stanowić dla nich odpowiednią osłonę przed agresją cesarstwa. W ten sposób Hemos stawał się swoistą kurtyną, zza której mogli oni dokonywać rajdów na ziemie cesarstwa i w razie potrzeby wracać pod jej osłonę.

Góry te stanowiły nie tylko osłonę czy też granicę władztwa Bułgarów, lecz pełniły także rolę bazy wypadowej, a przede wszystkim punktu obserwacyjnego dla wojsk bułgarskich. Takie zadania spełniały podczas wydarzeń związanych z wyprawą cesarza Justyniana II przeciwko Bułgarom w 708 roku ${ }^{10}$. Co prawda istnieje pogląd, że wyprawa ta była wymysłem Teofanesa ${ }^{11}$ lub błędem, który wkradł się we wspólne źródło jego Chronografii i Zarysu historii patriarchy Nikefora ${ }^{12}$, lecz nie jest on w pełni przekonywający ${ }^{13}$. W przypadku Georgija Ostrogorskiego decydującym argumentem za prawdziwością tego wydarzenia jest wzmianka o nim w dziele patriarchy Nikefora, z czego wynika, iż informację tę obaj historycy przejęli ze wspólnego źródła. Gdy idzie o uwagi Andreasa N. Stratosa powstaje pytanie, o jakie inne starcie pomiędzy Bizantyńczykami a Bułgarami koło Anchialos może chodzić? Nie mamy również żadnych danych dotyczących jakichś nieregularnych grup bułgarskich na terytorium wokół tej nadmorskiej twierdzy, a nie będących pod zwierzchnictwem Terweła ${ }^{14}$. Jedyna taka społeczność znana ze źródeł z tego okresu to tzw. grupa

${ }^{9}$ Niektórzy uczeni uważają, że najazdy te dotyczyły również niezdobytych jeszcze bizantyńskich ośrodków miejskich na terenie Mezji - П. Петров, Създаване на българската държава, w: История на България в четиринадесет тома, t. II, Първа българска държава, ред. Д. Ангелов, София 1981, s. 100; Б. Чолпанов, Е. Александров, Военна история на Първата българска държава (681-1018), w: История на българите, t. V, Военна история на българите от древността до наши дни, ред. Д. Зафиров, Е. Александров, София 2007, s. 74.

$10 \mathrm{O}$ tej wyprawie cf. В.Н. Златарски, История на българската държава през средните векове, t. I, pars 1, Епоха на хуно-българското надмощие (679-852), София 1918, s. 174; B. Primov, Bulgaria in the Eighth Century. A General Outline, „Byzantinobulgarica“, t. 5, 1978, s. 11-12; V. Beševliev, Die Protobulgarische Periode der bulgarischen Geschichte, Amsterdam 1981, s. 195-196; idem, Zwei Versionen bei Theophanes und Nikephoros dem Patriarchen, w: idem, Bulgarisch-Byzantinische Aufsaetze, Aldershot 1978, s. 363-367; Д. Ангелов, С. Кашев, Б. Чолпанов, Българска военна история от Античността до втората четвърт на Х в., София 1983, s. 189; C. Head, Justinian II of Byzantium, Madison 1972, s. 124-125; P. Soustal, op. cit., s. 78, 176; В. Гюзелев, Езическа България, w: И. Божилов, В. Гюзелев, История на средновековна България VII-XIV век, София 1999, s. 107-108.

${ }^{11}$ G. Ostrogorski, Dzieje Bizancjum, przekład pod red. H. Evert-Kappesowej, ${ }^{3}$ Warszawa 2008, s. 137 , przyp. 138 .

${ }^{12}$ A.N. Stratos, Byzantium in the Seventh Century, t. V, Justinian II, Leontius and Tiberius 685-711, Amsterdam 1980, s. 154.

13 Д. Ангелов, С. Кашев, Б. Чолпанов, op. cit., s. 190; M.J. Leszka, Butgaria i Chazarzy wobec walk o wtadzę w Bizancjum w poczatkach VIII w., „Balcanica Posnaniensia”, t. 9-10, 1999, s. 57-58, szczególnie s. 57, przyp. 48. Cf. W. Swoboda, Terwel, w: Stownik Starożytności Stowiańskich. Encyklopedyczny zarys kultury Stowian od czasów najdawniejszych do schytku wieku XII, t. VI, T-W, red. G. Labuda, Z. Stieber, Wrocław 1977, s. 64 (dalej: SSSt).

${ }^{14}$ Wyprawę na taką grupę dopuszczała także C. Head, op. cit., s. 124, 125. 
Kuwera, zasiedlająca obszary na zachód od Tesaloniki ${ }^{15}$, a więc w ogromnej odległości od teatru działań zbrojnych, opisywanych przez oba źródła ${ }^{16}$. Pozostaje więc tylko jedna możliwość zanegowania przekazu Nikefora i Teofanesa, a mianowicie, że autor ich wspólnego źródła zmyślił tę wyprawę, jako element budujący tzw. czarna legendę Justyniana $\mathrm{II}^{17}$. Podkreślić jednak muszę, że przyjmując nawet zasadność niektórych wątpliwości wspomnianych uczonych, twierdzenie, że do tej bitwy nie doszło nadal pozostaje wyłącznie hipotezą ${ }^{18}$. Tradycyjnie więc uważam, że ta kampania rzeczywiście miała miejsce.

A zatem, po przybyciu do Anchialos wojsko bizantyńskie rozproszyło się

na polach wyżej położonych,

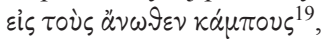

w celu poszukiwania furażu ${ }^{20}$. Zaniechano wszelkich środków ostrożności, mimo iż znajdowano się w pobliżu granicy z Bułgarią. W świetle przekazu Teofanesa

zwiadowcy bułgarscy obserwowali z gór daremne działania Romejów

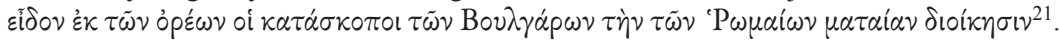

Wkrótce po tym nastąpił atak oddziałów bułgarskich. Opisując to natarcie zarówno patriarcha Nikefor, jak i Wyznawca, podkreślali element zaskoczenia ${ }^{22}$, któ-

${ }^{15}$ Cf. W. Swoboda, Kuber, w: SSSt, t. II, $F-K$, red. W. Kowalenko, G. Labuda, T. Lehr-Spławiński, Wrocław 1964, s. 554-555.

${ }^{16} \mathrm{Na}$ temat grup bułgarskich w Tracji we wcześniejszym okresie, jak również ich zaniku w VII stuleciu - Д. Ангелов, Образуване на българската народност, София 1981, s. 163. Najwcześniejsze osadnictwo bułgarskie na tym terenie datuje się na pierwszą połowę IX stulecia - Д. Момчилов, Култура и политика на Първото българско царство в Североизточна Тракия (по археологически данни), Варна 2007, s. 17-32, 44, 60-140, 205, 218-220; К. Станев, Тракия през ранното Средновековие, Велико Търново 2012, s. 116-120, 133-139.

${ }^{17} \mathrm{Na}$ jej temat cf. m.in. A. Kompa, Polityka wewnętrzna Justyniana II w świetle „Krótkiej historii” patriarchy Nicefora $i$ „Chronografi,” Teofanesa Wyznawcy, w: Cesarstwo Bizantyńskie. Dzieje. Religia. Kultura. Studia ofiarowane Profesorowi Waldemarowi Ceranowi przez uczniów na 70-lecie urodzin, red. P. Krupczyński, M.J. Leszka, Łask-Lódź 2006, s. 113-138.

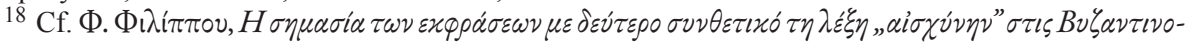

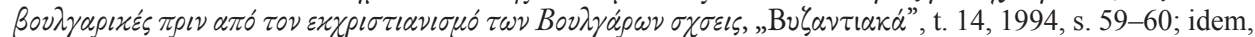

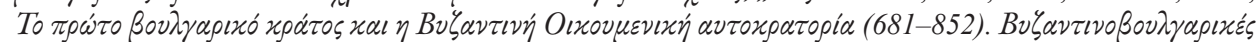

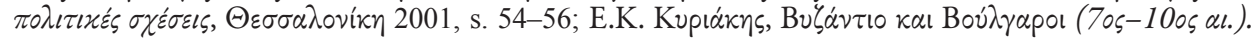

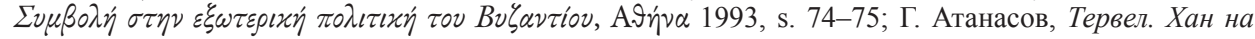
България и кесар на Византия, Силистра 2004, s. 53.

19 Teofanes, AM 6200, s. 376, 17-18; thum. - Testimonia, s. 59. Chodziło tu o pola pomiędzy Anchialos a południowym stokiem Wschodniej Starej Płaniny.

${ }^{20}$ Nikefor, Zarys historii, 43, s. 104, 4-5; Teofanes, AM 6200, s. 376, 19-20.

21 Teofanes, AM 6200, s. 376, 20-21; thum. - Testimonia, s. 59.

${ }^{22}$ Nikefor, Zarys historii, 43, s. 104, 4-7; Teofanes, AM 6200, s. 376, 21-22. Warto zwrócić uwagę, że podobny opis sytuacji wojennej wyszedł spod pióra Kekaumena. Otóż w czasie trwania rewolty przeciwko władzy bizantyńskiej, na czele której w latach 1040-1041 stali Piotr Deljan i Ałusjan, ten ostatni podjął się zadania zdobycia Tesaloniki. Gdy jednak przybył pod bizantyńską metropolię nie rozbił w należytym miejscu obozu, nakazując swoim oddziałom rozpocząć szturm. Wkrótce też, wyczerpani i znie- 
ry Bułgarzy uzyskali niewątpliwie dzięki atakowi z obszarów górskich, do ostatniej chwili osłaniających ich poczynania ${ }^{23}$.

Dimityr Angełow, Stefan Kaszew i Boris Czołpanow sugerują, że Bułgarzy obserwowali wroga i dokonali napadu ze wzniesień i zalesionego terenu, który leży na północny zachód od Anchialos ${ }^{24}$, co zdaje się wykluczać Bałkan Ajtoski, którego południowe stoki znajdują się w odległości około $10 \mathrm{~km}$ na północ od wspomnianej twierdzy. Interpretacja ta, choć prawdopodobna, nie jest w pełni zasadna.

Primo - badacze ci zakładają że Bułgarzy już wcześniej, przed rozłożeniem się wojsk cesarskich koło twierdzy, musieli przekroczyć granicę bizantyńsko-bułgarską (wówczas biegnącą wzdłuż płd. stoków Hemosu), by ukryć się na tych wzniesieniach. Źródła wskazują natomiast, że Terweł nie wystąpił jako agresor, dopóki nie nadarzyła się dogodna okazja, którą spostrzegł w nadmiernym rozproszeniu się oddziałów bizantyńskich. A za agresję należałoby uznać przekroczenie przez niego granic państwowych. Poza tym uprzednie wejście na terytoria bizantyńskie i rozłożenie się obozem na wspomnianych wzgórzach, zostałoby prawdopodobnie przez Bizantyńczyków zauważone.

Secundo - w cytowanym już przeze mnie fragmencie Teofanes wyraźnie wspomina, że zwiadowcy bułgarscy przebywali w górach, a nie na wzgórzach. Wydaje się więc, że wojsko bizantyńskie, a zwłaszcza jazda, rozproszyła się na znacznie większym terytorium w poszukiwaniu zaopatrzenia niż sądzą wspomniani uczeni. Niewątpliwie Bizantyńczycy mogli zbliżyć się do granicznych obszarów bułgarskich, gdzie zostali wypatrzeni przez Bułgarów - tak być może należy rozumieć informację Teofanesa, że Bizantyńczycy rozłożyli się na polach „wyżej położonych”, tzn. znajdujących się dalej na północ od twierdzy anchialskiej. Sądzę, że postawa bizantyńska wynikała $\mathrm{z}$ faktu, iż poruszali się po swoim terytorium ${ }^{25}$. Najwyraźniej Bułgarzy zebrali wojsko we wschodnim Hemosie i z jego stoków zaatakowali oddziały wroga, dopiero wtedy wkraczając na terytoria bizantyńskie ${ }^{26}$. Wydaje się też, że rekon-

chęceni bułgarscy wojowie rozeszli się po okolicy w poszukiwaniu wody lub miejsca do odpoczynku. Widząc bezładne błądzenie Bułgarów oraz brak obozu wojskowego, w którym mogliby się oni schronić, Bizantyńczycy dokonali wypadu zza murów miasta zadając nieprzyjaciołom klęskę - Кекавмен, Советь и рассказы. Поучение византийского полководиа XI века, 27, подготовка текста, введение, перевод с греческого и коментарий Г.Г. Литаврин, Санкт-Петербург 22003, s. 176, 18 - 178, 12. Cf. Ioannis Scylitzae synopsis historiarum, 27, ed. I. Thurn, Berolini et Novi Eboraci 1973 (dalej: Jan Skylitzes), s. 412, $88-414,26$, który nieco inaczej przedstawia te wydarzenia. Ten ostatni historyk piętnował jako słabość brak ufortyfikowanego i dobrze strzeżonego obozu, jak również niedbałe przemieszczanie się po okolicznym terenie, wśród wojsk Światosława kijowskiego, oblegających Akradiopol w 970 r. - Jan Skylitzes, 4, s. 288, $18-289,36$.

${ }^{23}$ П. Мутафчиев, Балканът в нашата история, w: idem, Книга за българите, ред. В. Гюзелев, София 1987, s. 67; J.V.A. Fine jun., op. cit., s. 74.

${ }^{24}$ Д. Ангелов, С. Кашев, Б. Чолпанов, op. cit., s. 189. Tak samo Б. Чолпанов, Е. Александров, op. cit., s. 76.

${ }^{25}$ Podobnie już S. Runciman, A History of the First Bulgarian Empire, London 1930, s. 32.

${ }^{26}$ Cf. X. і К. Шкорпил, Неизвестно писмо и крайбрежни насипи, „Известия на Варненското Археологическо Дружество“ 4, 1911, s. 85; П. Мутафчиев, История на българския народ /681-1323/, ред. В. Гюзелев, София 1986, s. 116; J.V.A. Fine jun., op. cit., s. 74; В. Гюзелев, op. cit., s. 107-108, 
strukcja wydarzeń zaproponowana przez wspomnianych uczonych odpowiada bardziej wydarzeniom związanym z bitwą nad Acheloos w 917 r. ${ }^{27} \mathrm{~W}$ takim układzie atak bułgarski z 708 r. należało by uznać za uderzenie prewencyjne, wyprzedzające spodziewane wkroczenie wojsk cesarskich na terytoria bułgarskie. Poza tym wspomniane przez autorów wzgórza stanowią daleką odnogę wschodniego Bałkanu.

W połowie VIII w. Hemos nadal był wykorzystywany, jako baza wypadowa i bariera, za którą można było się bezpiecznie schronić wraz z zagarniętymi łupami. Wykorzystał to chan Telec, który zgromadziwszy wojska ciężko uzbrojone i bitne, gwałtownie ( $\kappa \alpha \rho \tau \varepsilon \tilde{\omega} \varsigma)$ zaatakował pobliskie $(\tau \grave{\alpha} \pi \lambda \eta \sigma \alpha \alpha i \tau \varepsilon p \alpha)$ wsie i twierdze (фpoúpı) romejskie ${ }^{28}$. Sformułowanie o gwałtowności bułgarskiego ataku, użyte przez patriarchę Nikefora, miało podkreślać nie tylko barbarzyństwo, zaciekłość samych Bułgarów, lecz przede wszystkim postawę ich wodza. Pośrednio jednak wskazuje także na impet uderzenia, osiagnięty za sprawą nagłego pojawienia się oddziałów chańskich na obszarze Górnej Tracji. Zaskoczenie i siła bułgarskiego natarcia wynikały faktu dokonania ataku z obszaru górskiego. Pobliskie Bułgarom wsie i twierdze leżały niewątpliwie u podnóży i w pobliżu Starej Płaniny ${ }^{29}$, na co wskazuje chociażby greckie określenie tych ostatnich, mianowicie termin $\phi$ poúpı. To miano odnosiło się bowiem do pomniejszych, najczęściej nadgranicznych fortyfikacji.

Gdy 30 czerwca 763 r., w wyniku krwawej bitwy z Bizantyńczykami pod Anchialos, oddziały dowodzone przez chana bułgarskiego Teleca zostały zmuszone do ucieczki ${ }^{30}$, niewątpliwie pierwszym miejscem, w którym szukały schronienia, było pasmo staropłanińskie. Fakt ukrycia się w Hemosie nie wynikał wyłącznie z tego, że wycofując się na rodzime terytoria Bułgarzy siłą rzeczy musieli przekroczyć te góry, gdyż stanowiły one w tym czasie właściwą granicę pomiędzy obydwoma państwami. Schronienie się w górach było zabiegiem w pełni świadomym. Jeżeli bowiem wierzyć przekazowi Teofanesa, zanim wystąpił przeciwko armii Konstantyna V, władca bułgarski wziął jako sojuszników 20000 z sąsiednich ludów (patriarcha Nikefor uściśla, że chodziło o Słowian ${ }^{31}$ ) i

ubezpieczył się umieściwszy ich w fortyfikacjach

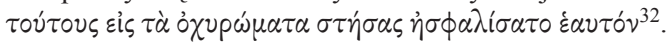

gdzie nawet sugestia, że na wieść o niebezpieczeństwie Terweł zajął się wpierw umocnieniem przełęczy staropłanińskich.

27 Cf. S. Runciman, The Emperor Romanus Lecapenus and his Reign. A Study of Tenth-Century Byzantium, Cambridge 1969, s. 55; Д. Ангелов, С. Кашев, Б. Чолпанов, op. cit., s. 268-272; J.V.A. Fine, op. cit., s. 149; Б. Чолпанов, Е. Александров, op. cit., s. 92-93.

${ }^{28}$ Nikefor, Zarys historii, 76, s. 148, 1-7.

29 Cf. V. Beševliev, Die Protobulgarische Periode..., s. 181, 213.

${ }^{30}$ Nikefor, Zarys historii, 76, s. 148, 12-14; Teofanes, AM 6254, s. 433, 8. Cf. Nicephori archiepiscopi Constantinopolitani antirrheticus tertius: Adversus Constantinum Copronymum, 72, w: PG, vol. C, kol. 508 B.

${ }^{31}$ Nikefor, Zarys historii, 76, s. 148, 12-13.

32 Teofanes, AM 6254, s. 433, 3-4; tłum. - Testimonia, s. 62. 
Dowodzi to tego, że Telec doskonale zdawał sobie sprawę z walorów obronnych jakie oferowało pasmo staropłanińskie i zawczasu postarał się o jego dodatkowe umocnienie. Uczynił tak właśnie na wypadek konieczności pospiesznego wycofania się z pola bitwy.

$\mathrm{Na}$ ten fragment $\mathrm{z}$ dzieła bizantyńskiego kronikarza nie zawsze zwracano w literaturze należytą uwagę, koncentrując się przede wszystkim na wydarzeniach związanych z samą bitwą i jej konsekwencjami ${ }^{33}$. Tymczasem w świetle powyższego przekazu wydaje się, że część sprzymierzonych oddziałów słowiańskich miała za zadanie zabezpieczać tyły armii Teleca, czyli strzec umocnień nadgranicznych pomiędzy Bizancjum a Bułgarią, a więc tych na obszarze Hemosu ${ }^{34}$. Wniosek ten może potwierdzać wcześniejszą konstatację, że dla uciekających oddziałów bułgarskich priorytetem było dotarcie do bezpiecznej linii gór, obsadzonej przez wzmiankowane posiłki.

W podobny sposób postapił chan Kardam, gdy w 792 r. wyprawiając się przeciwko armii bizantyńskiej stacjonującej na obszarach koło twierdzy Markele

33 O tej bitwie - В.Н. Златарски, op. cit., s. 243; G. Ostrogorski, op. cit., s. 157; W. Swoboda, Telec, w: SSSt, t. VI, s. 41; B. Primov, op. cit., s. 25-26; V. Beševliev, Die Feldzüge des Kaisers Konstantin V. gegen die Bulgaren, w: idem, Bulgarisch-Byzantinische Aufsaetze..., s. 10-11; idem, Die Protobulgarische Periode..., s. 213-215; Д. Ангелов, С. Кашев, Б. Чолпанов, op. cit., s. 205; I. Rochow, Byzanz im 8. Jahrhundert in der Sicht des Theophanes. Quellenkritisch-Historischer Kommentar zu den Jahren 715813, Berlin 1991, s. 179-181; P. Soustal, op. cit., s. 80, 176; Е.К. Кирı́́кทs, op. cit., s. 84-85; В. Гюзелев, op. cit., s. 116; Г.Г. Литаврин, Телец и его славянские союзники, w: Общото и специфичното в балканските култури до края на ХІХ век. Сборник в чест на проф. Василка Тъпкова-Заимова, ред. Г. Бакалов, София 1999, s. 44-45; Г.Н. Николов, Централизъм и регионализъм в ранносредновековна България (края на VII - началото на XI в.), София 2005, s. 78-79; K. Marinow, Zadania floty cesarskiej w wojnach bizantyńsko-butgarskich (VII-XI w.), w: Byzantina Europea. Księga jubileuszowa ofiarowana Profesorowi Waldemarowi Ceranowi, red. M. Kokoszko, M.J. Leszka, Łódź 2007, s. 384.

34 Д. Ангелов, С. Кашев, Б. Чолпанов, op. cit., s. 205. В.Н. Златарски, op. cit., s. 213-214, oraz s. 214, przyp. 2, słusznie stwierdził, że chodziło o umocnienia w górach na północ od Anchialos (podobnie Б. Примов, Г. Цанкова-Петкова, България през VIII в., w: История на България в четиринадесет mома.., s. 121), konkretnie na obszarze Góry lub Bałkanu Ajtoskiego. Ta bowiem część Hemosu ograniczała od północnego zachodu pole, na którym rozłożył obozem swą armię Konstantyn V (Братя Шкорпилови, Черноморското крайбрежие и съседните подбалкански страни в Южна България, „Сборник за Народни Умотворения, Наука и Книжнина”, t. 3, 1890, s. 3). Cf. V. Beševliev, Die Protobulgarische Periode..., s. 214-215, który uznał, że chodziło o fortyfikacje na drogach górskich prowadzących z Anchialos i Mesembrii do Odessos oraz J.V.A. Fine jun., op. cit., s. 77: Telec..., fortified his frontier with Byzantium, and then advanced into Thrace, przy czym nie konkretyzuje, czy chodzi o jego pierwszy łupieżczy najazd na Trację, czy już o przeciwstawienie się Konstantynowi. Bez względu na to jednak słuszny wydaje się jego pogląd o umocnieniu granicy, która wówczas przebiegała wzdłuż gór. Nie wydaje się prawdopodobne, by Telec obsadził Słowianami wcześniej zaatakowane twierdze trackie, gdyż Nikefor nie podał, czy Bułgarzy jakąkolwiek z nich zdobyli, a jeżeli tak, to czy zatrzymali je w swym posiadaniu. Stwierdził jedynie że Telec je zaatakował, nie wspomniał poza tym, by już wtedy towarzyszyły mu sprzymierzone oddziały słowiańskie - Nikefor, Zarys historii, 76, s. 148, 5-7. Natomiast Teofanes wyraźnie informował, że wystąpił z nimi dopiero na wieść o nadejściu Bizantyńczyków i to po to, by zabezpieczyć się - Teofanes, AM 6254, s. 433, 1-4. Żadne ze źródeł nie wspomina, by po zwycięskiej bitwie Konstantyn V musiał zdobywać jakieś twierdze lub miasta. Poza tym rozlokowywanie Słowian w przełęczach Starej Płaniny miało w Bułgarii już swoją tradycję - cf. V. Beševliev, Die Feldzüge..., s. 10; idem, Die Protobulgarische Periode..., s. 214; Г.Н. Николов, ор. cit., s. 83-84. 
wyszedł... z całym swym wojskiem i usadowił się w umocnieniach

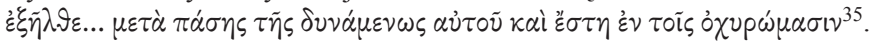

Tekst przekazu sugeruje bowiem, że ponownie mamy tu do czynienia z zabezpieczeniem nadgranicznych obszarów górskich w przededniu rozegrania bitwy, a co za tym idzie ze stworzeniem sobie bezpiecznego schronienia na wypadek klęski i ewentualnego odwrotu. Dodatkowo, przebywanie w fortyfikacjach na obszarze gór umożliwiało swobodną obserwację poczynań wroga ${ }^{36}$. Generalnie w tym okresie, gdy Hemos stanowił rzeczywistą granicę bizantyńsko-bułgarską był on dla Bułgarów pierwszym napotykanym schronieniem, gdyż powracając z terenów bizantyńskich, dopiero wkroczywszy na jego obszar mogli czuć się bezpiecznie.

Rok 811 przyniósł ze sobą wielką wyprawę cesarza Nikefora I przeciwko Bułgarii $^{37}$. Po nieudanej próbie zawarcia porozumienia pokojowego ze stacjonującym w podgórskiej twierdzy Markele cesarzem,

35 Teofanes, AM 6284, s. 467, 29-30; Chronica byzantina brevioria, 2, ed. P. Schreiner, vol. I, Einleitung und Text, Vindobonae 1975, s. 48, 13. Д. Ангелов, С. Кашев, Б. Чолпанов, op. cit., s. 214, twierdzą nawet, że chodziło tu o tereny koło znanej z późniejszych źródeł twierdzy Goloe i wzniesień na płd. od niej, które Б. Чолпанов, Е. Александров, op. cit., s. 78, sytuują koło współczesnej wsi Łozarewo. Z kolei V. Beševliev, Die Protobulgarische Periode..., s. 232, wiąże te umocnienia z przełęczą Werigawa (według niego obecnie Riszką-ibidem, s. 180), co w gruncie rzeczy odpowiada lokalizacji zaproponowanej przez wyżej wzmiankowanych uczonych. Twierdzenie Teofanesa (AM 6284, s. 468, 6-7), że po zwycięskim starciu Bułgarzy zgarnęli cały obóz bizantyński wraz z namiotem cesarskim wskazuje, że w dniu bitwy Bizantyńczycy opuścili Markele i wkroczyli wraz z taborami na teren klisur, w których umocnił się chan Kardam, prawdopodobnie zamierzając, po wygranej bitwie, przekroczyć góry - cf. E.K. Kupiákns, op. cit., s. 100.

${ }^{36}$ В. Гюзелев, op. cit., s. 122. O tej bitwie z 20 lipca 792 r. cf. G. Ostrogorski, op. cit., s. 165, 166167; В. Primov, op. cit., s. 37; V. Beševliev, Die Protobulgarische Periode..., s. 231-232; Д. Ангелов, C. Кашев, Б. Чолпанов, op. cit., s. 214-216; I. Rochow, op. cit., s. 257-258; E.K. Kupiákns, op. cit., s. 9597, 99, 100, 101; R.-J. Lilie, Byzanz unter Eirene und Konstantin VI. (780-802). Mit einem Kapitel über Leon IV. (775-780) von Ilse Rochow, Frankfurt am Main 1996, s. 181-182; Б. Чолпанов, Е. Александров, op. cit., s. 78.

${ }^{37} \mathrm{Na}$ jej temat cf. J.B. Bury, A History of the Eastern Roman Empire from the Fall of Irene to the Accession of Basil I. (A. D. 802-867), New York 1965, s. 344; В.Н. Златарски, op. cit., s. 255-260, 408-412; И. Дуйчев, Нови житийни данни за похода на имп. Никифора I в България през 811 год., „Списание на Българската Академия на Науките. Клон Историко-Филологичен и ФилософскоОбществен”, t. 26, 1937, s. 147-186; Щ. Атанасов, И. Дуйчев, Д. Ангелов, Г. Цанкова-Петкова, Д. Христов, Б. Чолпанов, Българското военно изкуство през феодализма, София 1958, s. 165172; I. Dujčev, La chronique byzantine de l'an 811, „Travaux et Mémoires”, t. 1, 1965, s. 216-254; W. Swoboda, Nicefor I, w: SSSt, t. III, s. 371-372; A. Kominis, Echi della battaglia dell'anno 811 tra Bizantini e Bulgari in testi agiografici, w: Actes du premier Congres International des Études Balkaniques et Sud-Est Européennes, Sofia, 26 âout - 1 septembre 1966, vol. III, Histoire (Ve-XVe ss.; XV $V^{e} X V I I^{e}$ ss.), red. V. Tăpkova-Zaimova, S. Dimitrov, E. Sarafova, Sofia 1969, s. 313-318; G. Ostrogorski, op. cit., s. 177; Б. Примов, Укрепване и териториално разиирение на българската държава през първата половина на IX в., w: История на България в четиринадесет тома..., s. 134-138; В. Бешевлиев, Крум и Никифор, „Studia Balcanica“, t. 17, 1983, s. 17-26; idem, Die Protobulgarische Periode..., s. 240-247; J. Wortley, Legends of Byzantine Disaster of 811, „Byzantion”, t. 50, 1980, s. 533-562; Д. Ангелов, С. Кашев, Б. Чолпанов, op. cit., s. 225-231; P.E. Niavis, The Reign of the Byzantine Emperor Nicephorus I (AD 802-811), Athens 1987, s. 236-248; T. Wasilewski, Historia Butgarii, ${ }^{2}$ Wrocław 1988, s. 48 
kiedy wkroczył do klisur, Bułgarzy dowiedzieli się o nadciagającym wielkim wojsku, a ponieważ jakoby nie czuli się na siłach, by stawić im opór, porzucając wszystko, co mieli, uciekli w góry

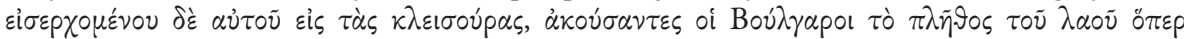

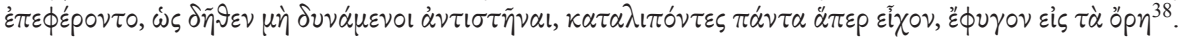

Fakt ten potwierdza Żywot św. Mikołaja Studyty, który jako żołnierz uczestniczył w wyprawie:

A gdy cesarz wszedł do klisur Bułgarii, Bułgarzy wspięli się na góry

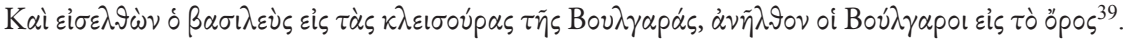

Oczywiście Krum nie dowiedział się o sile wojska cesarskiego i powadze bizantyńskich zamiarów dopiero w momencie wkroczenia wrogiej armii w góry, lecz wcześniej, o czym świadczy próba ułożenia się z Nikeforem I jeszcze przed jego wejściem na tereny bułgarskie ${ }^{40}$. Wydaje się, że w momencie przybycia Bizantyńczyków do Markele chan nie był w stanie bronić przełęczy wobec przeważającej liczebnie armii cesarskiej. Jest bardzo prawdopodobne, że władca bułgarski przebywał w bezpiecznych obszarach Starej Płaniny przez cały czas trwania bizantyńskiej kampanii, skąd mógł kierować poczynaniami swoich armii przeciwstawiających się wrogowi, który poruszał się na drodze do Pliski. Wydaje się, bowiem, że Krum nie dowodził osobiście żadną z armii bułgarskich, które Bizantyńczycy pokonali podczas walk o siedzi-

49; W. Treadgold, The Byzantine Revival 780-842, Stanford 1988, s. 170-175; I. Rochow, op. cit., s. 298

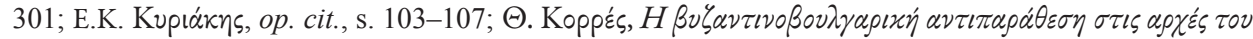

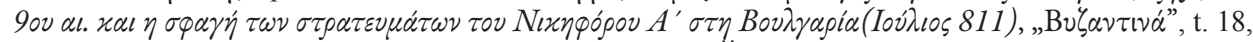
1995/1996, s. 167-193; В. Гюзелев, ор. cit., s. 128-131; М.Й. Лешка, Цели похода Никифора I против Болгар в 811 годy, w: Byzantium, New Peoples, New Powers: The Byzantino-Slav Contact Zone, from the Ninth to the Fifteenth Century, ed. M. Kaimakamova, M. Salamon, M. Smorag-Różycka, Cracow 2007, s. 55-62; Ж. Жеков, България и Византия. Военна администрачия VII-IX в., София 2007, s. 119121, 126, 127, 128; Ж. Жекова, Монетите на Никифор I Геник (802-811) и Плиска, w: ПлискаПреслав, t. VIII, Шумен 2000, s. 168-171; Г. Атанасова, Монетите на Никифор I Геник (802811), намерени в България, w: Пътуванията в средновековна България. Материали от първата национална конферениия "Пътуване към България. Пътуванията в средновековна България и съвремменият туризъм”, Шимен, 8-11.05.2008 г., ред. И. Йорданов, Велико Търново 2009,

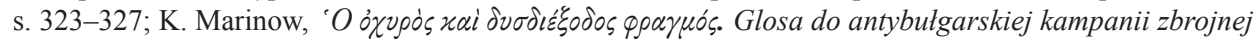
Nikefora I z 811 r., „Słupskie Studia Historyczne”, t. 17, 2011, s. 9-18.

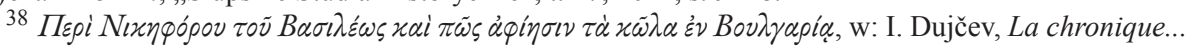
(dalej: O cesarzu Nikeforze), s. 210, 8-10; thum. Testimonia, s. 157.

39 Vita Nicolai Studitae, ed. I. Dujčev, w: Fontes Graeci Historiae Bulgaricae, vol. IV, ed. I. Dujčev, G. Cankova-Petkova, V. Tăpkova-Zaimova, L. Jončev, P. Tivčev, Serdicae [s.a.], s. 27. Cf. XV-wieczna, słowiańska wersja tego Żywotu: възи,,ошє въ гороч вльгарє - Разказ за св. Николай Студит в проложен сборник от XV в. за месеиче септември, октомври, ноември, декември и януари, w: В. Гюзелев, Извори за средновековната история на България (VII-XV в.) в австрийските ръкописни сбирки и архиви, т. І, Български, други славянски и византийски извори, София 1994, s. 16. И. Дуйчев, Нови житийни данни..., s. 158, sądził, że wśród oddziałów bułgarskich wycofujących się w głąb Starej Płaniny był sam Krum.

40 Teofanes, AM 6303, s. 490, 7-8. 
bę chańską i tuż po jej zajęciu. Nie zastali go też w samym pałacu ${ }^{41}$. Jest to wyłącznie moja hipoteza. Nie ma natomiast wattpliwości, że w momencie odwrotu wojska bizantyńskiego spod Pliski chan przebywał na terenie gór, gdyż szykował on tu zasadzkę na Bizantyńczyków.

W anonimowej Kronice roku 811 podkreślono, że Bułgarzy

zobaczyli z gór, że [Romejowie] krążą w zagubieniu

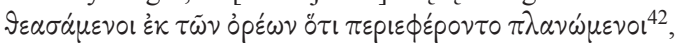

co wskazuje, że reszta sił bułgarskich, która nie została rozgromiona przez wojsko Nikefora, pozostawała wówczas na terenie Hemosu. Wydaje się pewne, że wśród nich przebywał władca bułgarski ${ }^{43}$. Stąd zapewne wysłał ludzi, którzy zorganizowali posiłki spośród sprzymierzonych Awarów i Słowian. Tutaj też zapewne sam doczekał się klęski Bizantyńczyków ${ }^{44}$.

Przy okazji należy po raz kolejny zwrócić uwagę na rolę pasma górskiego jako doskonałego punktu obserwacyjnego, z którego łatwo było śledzić poczynania wroga na terenie równinnym, samemu będąc zarazem ukrytym przed jego wzrokiem. W tym konkretnym przypadku mamy do czynienia z jedynym znanym w literaturze przykładem, gdy Bułgarzy śledzili z gór poczynania Bizantyńczyków na północ od pasma Bałkanu. Dodam, że w świetle jednego z późniejszych świadectw źródłowych część żołnierzy bizantyńskich uratowała się z klęski za sprawą ucieczki w głąb zalesionych

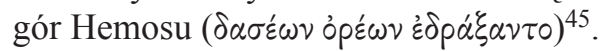

W tym miejscu warto wskazać na wybrane przykłady wykorzystywania gór Hemos i innych bałkańskich masywów jako schronienia dla różnorodnych oddziałów zbrojnych okresu średniowiecza i nowożytności. Otóż, na wieść o otoczeniu go przez Awarów w przełęczach Hemosu w 587 r. wojsko bizantyńskie zaczęło uciekać przez lasy porastające Starą Płaninę ${ }^{46}$. Także Rusowie, pokonani w bitwie przez wojska pozostające pod komendą Teodora z Mistei, jednego z dowódców bizantyńskich w czasie ruskiej kampanii cesarza Jana I Tzymiskesa w 971 r., uchodząc z pola

41 Teofanes, AM 6303, s. 490, 18-31; O cesarzu Nikeforze, s. 210, 10 - 212, 42. Według Teofanesa po zdobyciu Pliski Krum po raz wtóry zwrócił się do cesarza z prośbą o pokój. Uczynił to bez wątpienia za pośrednictwem posłów, sam zaś znajdował się poza zasięgiem armii bizantyńskiej. Nikefor był bowiem ciaggle wrogo usposobiony wobec niego, stąd gdyby Krum wpadł w jego ręce, źródła nie omieszkałyby o tym wspomnieć. Zwłaszcza, że podkreśliły, iż Bizantyńczycy zdobyli i spalili pałac Kruma oraz przypadł im w udziale skarbiec Kruma - Teofanes, AM 6303, s. 490, 24-27; O cesarzu Nikeforze, s. 212, 17-18.

42 O cesarzu Nikeforze, s. 212, 42-43; tłum. - Testimonia, s. 160 (z moimi poprawkami - K.M.).

43 Przebywanie Bułgarów w górach poświadcza także przekaz Gesta Episcoporum Neapolitanorum, pars II, 47, ed. G. Waitz, w: MGH.SRLI, s. 427, 35-38. Cf. poczynania wodza bizantyńskiego Komentiola, który podczas działań przeciwko Awarom w 587 r., także ukrywał się z wojskiem w lasach Starej Płaniny - Teofanes, AM 6079, s. 258, 9-12.

44 Pobyt Kruma w Hemosie po wkroczeniu Nikefora do Bułgarii przyjmują również J.V.A. Fine jun., op. cit., s. 96-97; P.E. Niavis, op. cit., s. 239-240.

45 Menologii graecorum. Pars tertia: a mense Martio ad Augustum, w: PG, vol. CXVII, kol. $556 \mathrm{~B}$.

46 Teofanes, AM 6079, s. 257, $29-258,5$ 
bitewnego szukali ratunku w pobliskich górach i tamtejszych głębokich, i gęsto zarośniętych, dolinach. Pod ich osłoną dotarli do Dorostolonu, w którym przebywał książę Światosław ${ }^{47}$. Po klęsce nad rzeką Sperchejos w 997 r. Samuel, władca bułgarski, i Roman, jego syn, ocalili swoje życie, wpierw udając martwych, następnie zaś uciekając, pod osłoną nocy, w góry Etolii, by ich szczytami dotrzeć bezpiecznie do Pindosu i samej Bułgarii ${ }^{48}$. A zatem udało im się pokonać takie duże odległości dzięki poruszaniu się pod osłoną gór. W górach schronienia przed wojskami cesarza Bazylego II szukali także synowie cara Jana Władysława, mianowicie Presjan, Ałusjan i Aaron (w masywie Tmoros/Tomor, w dzisiejszej Albanii), jak również Iwac (w paśmie Brochot, dziś Morawe na pograniczu albańsko-macedońskim) i Nikulitza (przekaz nie precyzuje, w którym masywie, podając ogólnie, że był ukryty gdzieś w górach), dowódcy wojsk bułgarskich ${ }^{49}$. Po klęsce w górach Zety, w 1042 r., żołnierze bizantyńscy ukryli się w tamtejszych zaroślach, lasach i kotlinach, a nawet szukali schronienia wdrapując się na szczyty górskie ${ }^{50}$. Tak samo po klęsce w bitwie z Pieczyngami w 1087 r., na terenie Paristrionu, część żołnierzy bizantyńskich, w tym jeden $z$ dowódców, mianowicie Jerzy Paleolog, chowała się w lasach i na wzniesieniach Hemosu ${ }^{51}$. Masyw Bałkanu stanowił również skuteczne schronienie dla Bułgarów, bądź to ukrywających się przed prześladowaniami ze strony Turków, bądź to zbuntowanych przeciwko władzy tureckiej, jeszcze w drugiej połowie XIX w. ${ }^{52}$ Przykłady te służą jedynie ilustracji, oraz potwierdzeniu, tezy o powszechności praktyk wojskowych stosowanych przez wojska bułgarskie.

Podkreślić jednak należy, że góry nie stanowiły jedynego schronienia przed przeciwnikiem. W obliczu wrogiego najazdu ludność równin chowała się przede wszystkim za murami miast lub w pobliskich lasach. W tym miejscu przypomnieć jednak należy, że Stara Płanina była i nadal należy do gęsto zalesionych pasm górskich. Generalnie rzecz ujmując pościg za zwyciężonym przeciwnikiem na terenie równinnym był znacznie łatwiejszy i skuteczniejszy. W związku z tym często kończył się dla pokonanego tragicznie, zwłaszcza jeżeli w pobliżu nie znajdowało się jakieś ufortyfikowane miasto, w którym mógłby się schronić. W takiej sytuacji brak dobrego wierzchowca równał się zazwyczaj wyrokowi śmierci. W górach natomiast pieszemu było łatwiej ukryć się i uratować, gdyż jazda wierzchem nie zawsze była tam możliwa,

47 Jan Skylitzes, 11, s. 298, $21-299,31$.

48 Jan Skylitzes, 23, s. 342, 43-47.

49 Jan Skylitzes, 41, s. 359, 26-38; 42, s. 360, 49-55; 43, s. 363, 43-47.

50 Jan Skylitzes, 2, s. 425, 92-97.

51 Annae Comnenae Alexias, VII, 4, 2-4, ed. D.R. Reinsch, A. Kambylis, vol. I, Berolini et Novi Eboraci 2001, s. 215, 84 - 216, 93. Inny przypadek podobnego postępowania, na innym terytorium górskim - Ioannis Cinnami epitome rerum ab Ioannae et Alexio Comnenis gestarum, III, 3, ed. A. Meineke, Bonnae 1836, s. 95, 16-17.

52 Ф. Каниц, Дунавска България и Балканът. Историческо-географско-етнографски пътеписни проучвания от 1860-1879 2., t. II, прев. П.Г. Горбанов, София [s.a.], s. 41, 131-132, 162. 
a zwykle nie było mowy o galopowaniu ${ }^{53}$. Wyraźnie kontrastuje to szansę uratowania się, nawet bez konia bojowego, w górach i na równinie.

I tak, analiza konkretnych informacji źródłowych, głównie z VIII-IX w., pozwala stwierdzić, że już w okresie ustanowienia chanatu nad dolnym Dunajem Bułgarzy uczynili z gór Hemos (Starej Płaniny i Srednej Gory) stałą osłonę, spoza której dokonywali najazdów na terytoria bizantyńskiej Tracji. Góry pełniły także rolę bazy wypadowej (680/681 r., 763 r., 792 r.) i punktu obserwacyjnego, z którego śledzono poczynania wojsk bizantyńskich działających zarówno u południowych, jak i północnych podnóży masywu (708 r., 763 r., 811 r.). Wykorzystywano je także w roli miejsca schronienia, do którego wycofywały się pokonane oddziały bułgarskie (763 r., 811 r.).

\title{
THE HAEMUS MOUNTAINS AS A SHELTER, AN ATTACK OUTPOST AND AN OBSERVATION POST IN THE LIGHT OF THE BULGARIAN-BYZANTINE MILITARY RELATIONS IN THE EARLY MIDDLE AGES
}

\author{
Summary
}

After the analysis of sources (coming mainly from the period of the 8th-9th centuries), the author of the article claims that still from the outset of the khanate on the lower Danube, Bulgarians made the Haemus Mountains (Stara Planina and Sredna Gora) a permanent protective barrier from behind which they could launch their attacks against the territory of Byzantine Thrace. The mountains functioned as an attack outpost (680/681, 763 and 792) and a convenient observation post, which was used to monitor the Byzantine military stationed both at the northern as well as southern foot of the range $(708,763,811)$. The mountains were also used as a shelter to which the defeated Bulgarian troops would retreat $(763,811)$.

${ }^{53} \mathrm{~K}$. Marinow, Hemus jako baza wypadowa i miejsce schronienia w okresie walk o restytucje państwowości butgarskiej pod koniec XII i na poczqtku XIII wieku, w: Cesarstwo Bizantyńskie..., s. 197198. 
